\title{
Borehole Observatory Installations on IODP Expedition 306 Reconstruct Bottom-Water Temperature Changes in the Norwegian Sea
}

\section{Introduction}

The ocean covers $70 \%$ of the Earth's surface, and because of its fluid motion and large thermal inertia, it plays a central role in redistributing heat about the globe and in shaping the Earth's climate. The northern North Atlantic is the primary deep ventilator of the world ocean, and it is now recognized that deep-water production is closely related to global climate (Broecker et al., 1985). Despite the importance of North Atlantic Deep Water to global and regional climate, there is a lack of long-term observations of temperature and salinity variations. Surface and near-surface measurements show natural variability on timescales of decades (Wunsch, 1992; Gammelsrød et al., 1992). The few deep oceanographic observations indicate that the thermohaline structure of the

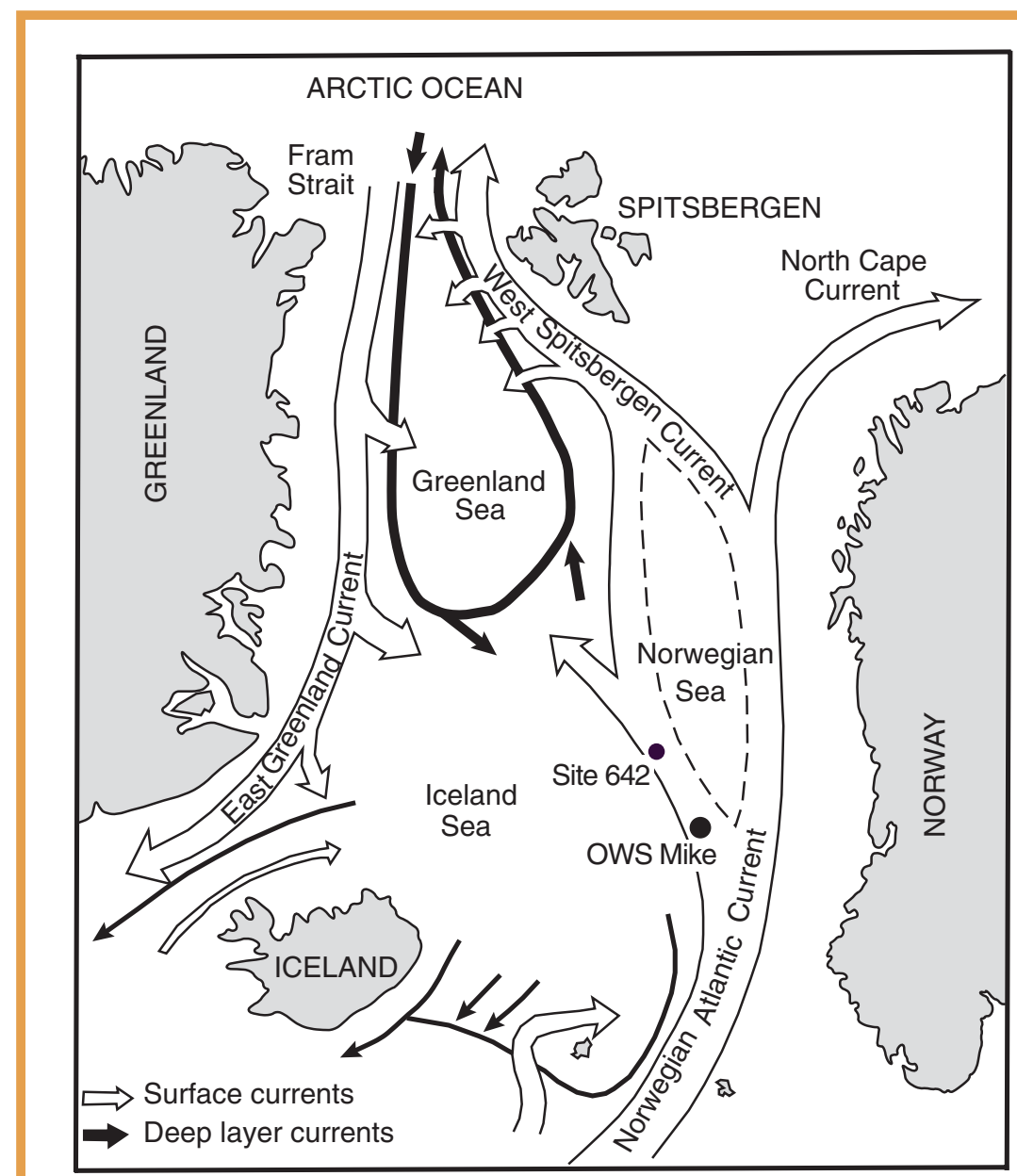

Figure 1. Location map of the Norwegian Sea and Vøring Plateau showing ODP Site 642 and Ocean Weather Ship Station "Mike" (modified from Gammelsrød et al., 1992).
North Atlantic has changed over the past twenty to thirty years and that bottom-water temperatures (BWT) have varied significantly (Brewer et al., 1983; Roemmich and Wunsch, 1984; Antonov, 1993). We hypothesize that, assuming purely conductive heat transfer, temperature profiles obtained from beneath the seafloor can be used to reconstruct BWT histories at timescales of decades to a century. The conductive thermal regime of the oceanic crust and sediment reflects the superposition of two processesthe long-term, outward heat flow from the Earth's deep interior that changes on timescales of millions of years, and short-term perturbations to this regime resulting from changes in BWT at the seafloor. These thermophysical perturbations provide a straightforward measure of temperature, not a proxy. Changes in BWT diffuse slowly downward through marine sediment because of its low thermal diffusivity $\left(\sim 1 \times 10^{-6} \mathrm{~m}^{2} \mathrm{~s}^{-1}\right)$ such that excursions in BWT that occurred 100 years ago now appear as maximum temperature anomalies at a depth of $40 \mathrm{~m}$. Resolution analysis indicates that a 100 -year record of temperature change is potentially recoverable from high-precision temperature logs in boreholes $150 \mathrm{~m}$ deep, with the deeper part used to estimate the background thermal regime. If this hypothesis is correct, and given that seafloor sediments continuously incorporate changes in BWT, it is theoretically possible to reconstruct BWT histories anywhere in the ocean.

The primary objectives of this experiment and borehole installation during IODP Expedition 306 are to document BWT variations, monitor their downward propagation beneath the seafloor over a five-year period, investigate the feasibility of reconstructing BWT variations over longer time periods, and establish whether observed BWT variations reflect long-term climate trends or random fluctuations expected in a complex fluid system.

\section{Previous Work}

Several studies have identified BWT variations from temperature profiles measured in sediments. In the Denmark Strait, for 
example, BWT has fluctuated on the order of $0.4^{\circ} \mathrm{C}$ (Lachenbruch and Marshall, 1968). Along the Reykjanes Ridge (Sclater and Crowe, 1979), temperature profiles are apparently linear between $7.5 \mathrm{mbsf}$ and $12.5 \mathrm{mbsf}$ (the base of the measurements), but show a sharp decrease $\left(\sim 0.4^{\circ} \mathrm{C}\right)$ in the upper $5 \mathrm{~m}$, consistent with an annual BWT fluctuation. Other studies documenting BWT variations based on sediment temperature profiles include the Bay of Biscay (Foucher and Sibuet, 1980), Bermuda Rise (Galson and Von Herzen, 1981), the Canadian Beaufort Shelf (Taylor and Allen, 1987), the Gulf of Mexico (Cathles and Nunns, 1991) and the Scotia Sea (Barker and Lawver, 2000). Across the Norwegian margin at shallow water depths of 600-800 m, Vogt and Sundvor (1996) attributed curvature in thermal gradients to the upward movement of pore fluids, although they could not rule out BWT variations. Two studies of available oceanic BWT time series (Lachenbruch and Marshall, 1968; Cathles and Nunns, 1991) successfully modeled perturbations in temperature profiles in terms of deep water movements; however, the time span of the inferred results was limited by the length of the gravity-driven probe used to make the measurements.

\section{Experimental Setting}

The Norwegian Sea (Fig. 1) is an important source of Northern Hemisphere deep water (Kushnir, 1994; Weaver et al., 1999). While the upper few hundred meters of the Norwegian Sea are dominated by the warm, saline water of the Norwegian Atlantic current, the bottom water is a product of Greenland Sea Deep Water and Arctic Ocean Deep Water (Swift and Koltermann, 1988). These deep water masses are an important source of intermediate and deep water in the Northern Hemisphere and contribute significantly to North Atlantic Deep Water production; hence they ventilate the world ocean via global thermohaline circulation. ODP Site 642 lies at a water depth of approximately $1300 \mathrm{~m}$ on the Vøring Plateau in the Norwegian Sea (Fig. 1). This represents an ideal location to investigate the feasibility of reconstructing BWT from temperature profiles measured beneath the seafloor for three reasons: 1) the Norwegian Sea is in a climatically sensitive area, 2) existing data indicate that the sedimentary environment is suitable for this experiment, and 3) it is located near Ocean Weather Ship Station (OWS) "Mike," which has operated continuously since 1948 providing the longest and most complete time series of monthly bottom-water temperature and salinity measurements from the deep ocean (Gammelsrød et al., 1992, Østerhus et al., 1996).

Temperature data from a depth of $1500 \mathrm{~m}$ at OWS Mike show a minimum of $-0.89^{\circ} \mathrm{C}$ in 1983 increasing to a maximum of $-0.80^{\circ} \mathrm{C}$ in 2000 (Østerhus et al., 1996), a difference of $90 \mathrm{mK}$ over seventeen years. The recent warming of the Norwegian Sea deep water is tied to warming of Greenland Sea deep water and has been interpreted as a sign that deepwater production ceased in the Greenland Sea (Østerhus et al., 1996). These data will be used to check the efficacy of our

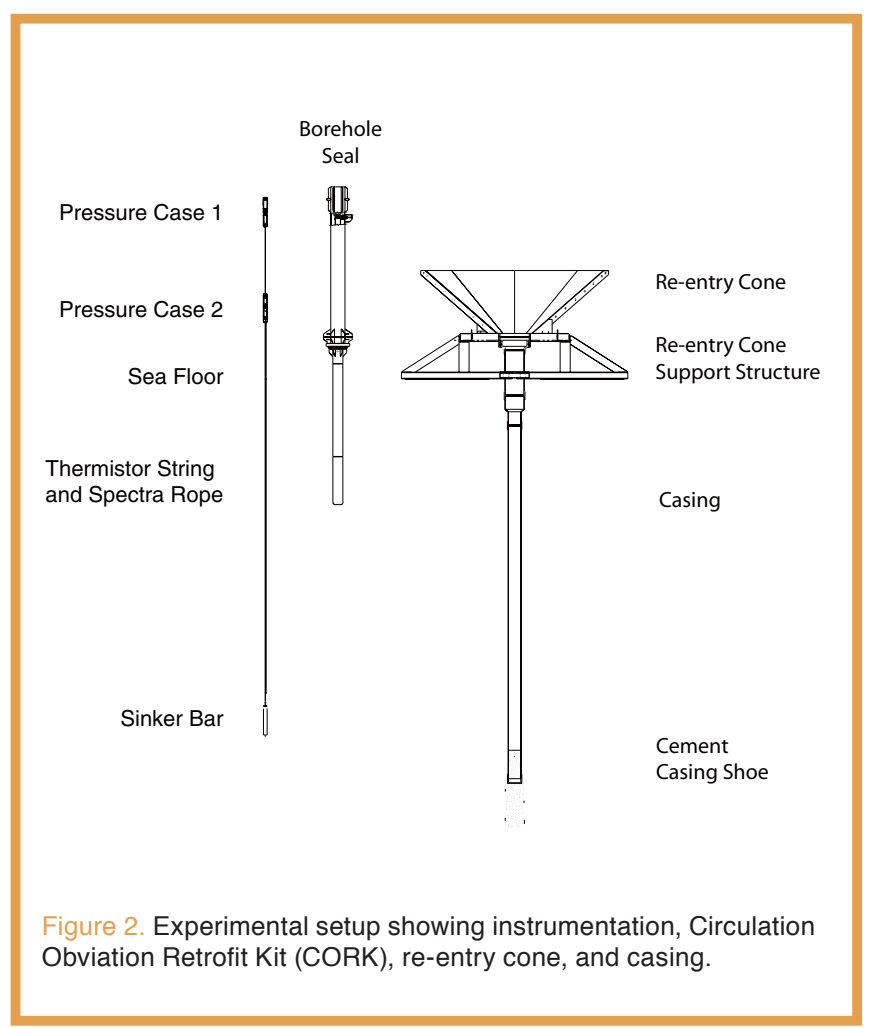

measurement technique and analysis. Core recovery and quality at ODP Site 642 were high and revealed approximately $400 \mathrm{~m}$ of Neogene and Quaternary pelagic and hemipelagic sediment overlying volcanic basement (Eldholm et al., 1987). An important factor for assuring the success of this experiment is that the sedimentary thermal regime must be entirely conductive. Unfortunately, at the time of drilling Site 642, no temperature measurements were made. Candidate processes leading to advective heat flow include crustal hydrothermal circulation, pore-water advection, and fluid convection within the borehole itself. Hydrothermal processes are unlikely to disturb the shallow thermal regime because of the thick sedimentary cover and because Site 642 sits on a 55-Ma-old passive margin in an area of low background heat flow $\left(\sim 50 \mathrm{~mW} \mathrm{~m}^{-2}\right)$. The low permeability of marine muds encountered at this site (Eldholm et al., 1987) makes pore-water advection unlikely. Variations in major elements and isotope composition determined on interstitial fluid samples are consistent with diagenetic and alteration reactions and do not show evidence of an advective signal (Aagaard et al., 1989; Whiticar and Faber, 1989). To minimize the possibility of convection within the borehole, we minimized the hole diameter and filled it with low viscosity bentonite mud.

\section{Experimental Design}

We chose not to re-enter Hole 642E for installing the experiment during IODP Expedition 306 because this hole has remained open for approximately 20 years, and advective heat flow between the top of the hole and the ocean and convection within the hole would negatively impact the experiment. Additionally, Hole 642E penetrates basement, which could provide a conduit for fluid flow. Temperature 


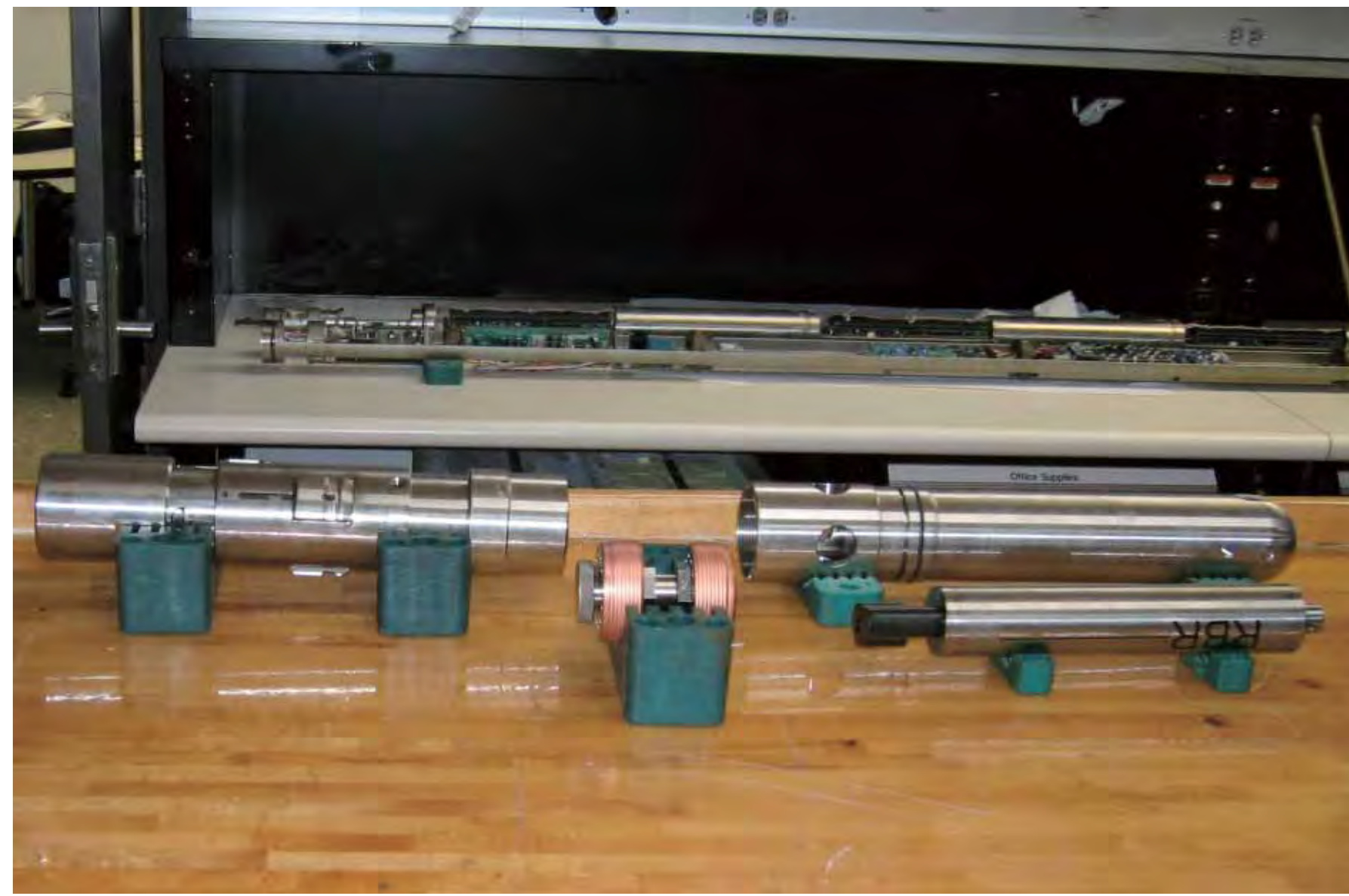

Figure 3. Assembling the data logger and thermistor string in the JOIDES Resolution Downhole Laboratory. The figure shows upper components of instrumentation. In the background (left) is the XN lock mandrel for latching the system into the CORK assembly. Foreground middle shows slip joint connecting the mandrel to battery pack housing. Foreground (right) shows pressure casing for bottom water temperature thermistor and back-up battery pack. Below this assembly is another housing containing batteries, data logger, and thermistor string.

logs made in Hole 642E during IODP Expedition 306 confirmed the upflow of water. Instead, we drilled a new hole at Site U1315, approximately $2 \mathrm{~km}$ south-southeast of Site 642 , at a water depth of $1283 \mathrm{~m}$. Hole U1315A was drilled to a depth of $179.07 \mathrm{mbsf}$ and cased with 10-3/4 inch casing (Fig. 2). The base of the casing was cemented, and the casing string was displaced with bentonite mud. The thermistor string is connected to a data logger and external battery at the pressure case.

The Circulation Obviation Retrofit Kit (CORK) instrumentation in Hole U1315A consists of two pressure cases and a thermistor string (Fig. 3). Diffusion of the thermal wave through the subsurface is monitored with a 150-m armored thermistor string deployed in a cased and sealed borehole. Twenty-four thermistors increase in spacing downstring to account for the natural scale of thermal diffusion. The thermistors have a resolution of $<5 \times 10^{-5 \circ} \mathrm{C}$, are calibrated using the National Institute of Standards and Technology (NIST) traceable reference standards, and have a reported uncertainty of $<0.2 \mathrm{mK}$. The top pressure case houses a salinity and temperature sensor that sits in the water column via an elevated re-entry cone and is designed to monitor the bottom water. Data are collected every hour, based on expected battery life and the five-year duration of the experiment.

\section{Significance}

Although variations in bottom-water temperature have been shown to be important in terms of climate change, and modern records show that these variations are significant over the last few decades, no data exist for documenting these variations over the past 100 years. This study is aimed at reconstructing BWT variations and, through comparisons with other geophysical and geochemical data, investigating ties between bottom-water formation and large-scale forcing of deep thermohaline circulation on a timescale of 10-100 years. A successful experiment offers the exciting possibility of establishing transects of such measurements across climatologically important gateways such as the Reykjanes Ridge and, more generally, reconstructing and monitoring BWT histories with confidence anywhere in the ocean.

\section{Acknowledgements}

We thank Captain Peter Mowatt, his officers, and crew for their efforts that made this work possible. Particular thanks go to Drilling Superintendent Tim McCown and Operations Manager Mike Storms. Instrumentation and salary support to R. Harris was provided by National Science Foundation Grant OCE-0424800. 


\section{The IODP Expedition 306 Scientists}

T. Kanamatsu (Co-Chief Scientist), R. Stein (Co-Chief Scientist), C. Alvarez-Zarikian (Staff Scientist), E. Aboud, G. Acton, K. Akimoto, I. Bailey, K. Bjørklund, H. Evans, N. Fang, P. Ferretti, J. Gruetzner, Y. Guyodo, K. Hagino, D. Kulhanek, R. Harris, K. Hatakeda, J. Hefter, S. Higgins, S. Judge, F. Nanayama, S. Nielsen, M. Ohno, H. Rashid, F. Sanchez, A. Voelker, and Q. Zhai.

\section{References}

Aagaard, P., Egeberg, P.K., and Smalley, P.C., 1989. Diagenetic reactions in Leg 104 sediments inferred from isotope and major element chemistry of interstitial waters. In Eldholm, O., Thiede, J., Taylor, E., et al., Proc. ODP, Sci. Results, 104: College Station, TX (Ocean Drilling Program), 273-280.

Antonov, J.I., 1993. Linear trends of temperature at intermediate and deep layers of the North Atlantic and North Pacific Oceans: 1957-1981. J. Climate, 6:1928-1942. d oi:10.1175/1520-0442(1993)006<1928: LTOTAI $>2.0 . \mathrm{CO} ; 2$

Barker, P.F., and Lawver, L.A., 2000. Anomalous temperatures in central Scotia Sea sediments-bottomwater variation or pore water circulation in old ocean crust. Geophys. Res. Lett., 27:13-16. doi:10.1029/ 1999GL008381

Brewer, P.G., Broecker, W.S., Jenkins, W.J., Rhines, P.B., Rooth, C.G., Swift, J.H., Takahashi, T., and Williams, R.T., 1983. A climatic freshening of the deep Atlantic north of $50^{\circ} \mathrm{N}$ over the past 20 years. Science, 222:1237-1239.

Broecker, W.S., Peteet, D.M., and Rind, D.H., 1985. Does the ocean-atmosphere system have more than one stable mode of operation? Nature (London, U. K.), $315: 21-26$.

Cathles, L.M., and Nunns, A.G., 1991. A temperature probe survey on the Louisiana Shelf: effects of bottomwater temperature variations. AAPG Bull., 75:180-186.

Eldholm, O., Thiede, J., Taylor, E., et al., 1987. Proc. ODP, Init. Repts., 104: College Station, TX (Ocean Drilling Program).

Foucher, J.-P., and Sibuet, J.-C., 1980. Thermal regime of the northern Bay of Biscay continental margin in the vicinity of the DSDP Sites 400-402. Philos. Trans. $R$. Soc. London, Ser. A, 294:157-167.

Galson, D.A., and von Herzen, R.P., 1981. A heat flow survey on anomaly MO south of Bermuda Rise. Earth Planet. Sci. Lett., 53:296-306. doi:10.1016/0012821X(81)90035-2

Gammelsrød, T., Østerhus, S., and Godøy, Ø., 1992. Decadal variations of ocean climate in the Norwegian Sea at Ocean Station 'Mike' $\left(65^{\circ} \mathrm{N} 2^{\circ} \mathrm{E}\right)$. ICES J. Mar. Sci., 195:68-75.

Kushnir, Y., 1994. Interdecadal variations in North Atlantic sea-surface temperature and associated atmospheric conditions. J. Clim., 7:141-156. doi:10.1175/15200442(1994)007<0141:IVINAS>2.0.CO;2

Lachenbruch A.H., and Marshall, B.V., 1968. Heat flow and water temperature fluctuations in the Denmark Strait. J. Geophys. Res., 73:5829-5842.

Østerhus, S., Gammelsrød, T., and Hogstad, R., 1996. Ocean weather ship station Mike $\left(66^{\circ} \mathrm{N} 2^{\circ} \mathrm{E}\right)$ - the longest existing homogeneous time series from the deep ocean. Int. WOCE Newsl., 24:31-33.

Roemmich, D., and Wunsch, C., 1984. Apparent changes in the climatic state of the deep North Atlantic Ocean. Nature (London, U. K.), 307:447-450. doi:10.1038/ $307447 \mathrm{a} 0$

Sclater, J.G., and Crowe, J., 1979. A heat flow survey at anomaly 13 on the Reykjanes Ridge: a critical test of the relation between heat flow and age. J. Geophys. Res., 84:1593-1602.

Swift, J.H., and Koltermann, K.P., 1988. Origin of Norwegian Sea deep water. J. Geophys. Res., 93:3563-3569.

Taylor, A.E., and Allen, V., 1987. Shallow sediment temperature perturbations and sediment thermal conductivities, Canadian Beaufort Shelf. Can. J. Earth Sci., 24:2223-2234.

Vogt, P.R., and Sundvor, E., 1996. Heat flow highs on the Norwegian-Barents-Svalbard continental slope: deep crustal fractures, dewatering, or 'memory in the mud'? Geophys. Res. Lett., 34:3571-3574. doi:10.1029/96GL03259

Weaver, A.J., Bitz, C.M., Fanning, A.F., and Holland, M.M., 1999. Thermohaline circulation: high latitude phenomena and the difference between the Pacific and Atlantic. Annu. Rev. Earth Planet. Sci., 27:231-285.

Whiticar, M.J., and Faber, E., 1989. Carbon, hydrogen, and oxygen isotope distribution in the interstitial fluids of ODP Leg 104, Holes 642B, 642D, 643A, and 644A, Vøring Plateau, Norwegian Sea. In Eldholm, O., Thiede, J., Taylor, E., et al., Proc. ODP, Sci. Results, 104: College Station, TX (Ocean Drilling Program), 285-290.

Wunsch, C., 1992. Decade-to-century changes in ocean circulation. Oceanography, 5:99-106.

\section{Author}

Robert N. Harris, College of Oceanic and Atmospheric Sciences, Oregon State University, Corvallis, OR 97333, U.S.A., e-mail: rharris@coas.oregonstate.edu

\section{Related Web Link}

http://iodp.tamu.edu/publications/PR/306PR/306PR.html 